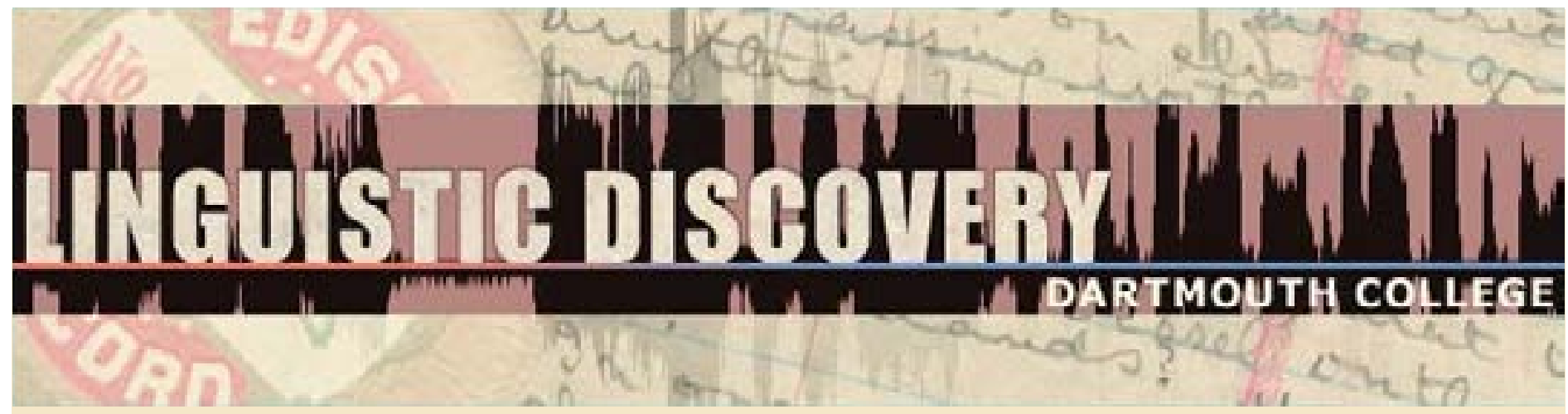

\begin{tabular}{|l|}
\hline Volume 9 \\
Issue 2 \\
2011 \\
\hline
\end{tabular}

\title{
On the Expression of Spatial Relations in Ardeşen-Laz
}

Silvia Kutscher

Humboldt University Berlin

doi: $10.1349 / P S 1.1537-0852 . A .394$

url: http://journals.dartmouth.edu/cgi-bin/WebObjects/ Journals.woa/1/xmlpage/1/article/394

\section{Linguistic Discovery}

Published by the Dartmouth College Library Copyright to this article is held by the authors. ISSN 1537-0852 linguistic-discovery.dartmouth.edu 


\title{
On the Expression of Spatial Relations in Ardeșen-Laz
}

\author{
Silvia Kutscher
}

Humboldt University Berlin

This paper gives an overview of the means of expression which are used in descriptions of spatial scenes in Laz. With motion verbs, Laz uses the satellite-framed strategy with motionmanner conflation in the verbal root. Path information is given in preverbal satellites. With respect to locative expressions it belongs to the multi-verb-type languages. Hence, considering the lexical properties of the verb roots, Laz is a rather ordinary language. However, with respect to the semantics of its spatial case system and the semantics of the satellites, i.e. its system of spatial preverbs, it will be shown that Laz is typologically rather unusual.

\section{Introduction ${ }^{1}$}

As a sister language of Georgian, spoken on the south-eastern coast of the Black Sea, Laz is the only member of the South Caucasian family which is spoken primarily outside of Georgia. The vast majority of its speakers live in Turkey and are bilingual. Laz is a severely endangered language and is used almost exclusively as a means of oral communication among family members. While most Laz older than forty are competent speakers of the language, an increasing number of young Laz are fluent only in Turkish, with a rapid decline of language competence with ethnic Laz younger than twenty (Kutscher 2008).

The data on Ardeşen-Laz presented in this article were collected during several fieldwork stays in Turkey. The major part of the data are elicited utterances on the basis of visual stimuli developed by the Language and Cognition Group of the Max Planck Institute for Psycholinguistics in Nijmegen, namely the Topological Relations Picture Series (TRPS) and the Picture Series for Positional Verbs (PSPV). These two stimuli are booklets with drawings and photographs showing topological configurations and were tested with 4 fluent speakers of Laz. These data are supplemented by spontaneous elicitations and some overheard utterances during the fieldwork stay, excerpts of spoken narratives collected during an earlier fieldwork trip to Ardeşen (published as Kutscher \& Genç 1998), and elicited data from some speakers of Laz living in Germany.

\section{Some Basic Facts on Ardeşen-Laz}

Laz as is spoken in Turkey is divided into four dialectal variants which are named after the urban centers around which the variant is spoken. The dialects are named either after the Turkish or the Laz name of the corresponding city (Turkish/Laz: Pazar/Atina, Ardeşen/Art'aşeni, FındıklıArhavi/Vitse-Arǩabi, Hopa/Xopa). The dialects are all of equal sociolinguistic status since a standard variety of Laz has not been established (cf. Kutscher 2001, chapter 1). The variety of Laz discussed here is the one spoken in the city of Ardeşen and the villages of the Ardeşen region. Although this dialect (Ardeşen-Laz) is more or less similar to the other dialects with respect to verb morphology, it differs considerably from other Laz varieties with respect to the

\footnotetext{
${ }^{1}$ I would like to thank Ioana Chitoran, Denis Creissels, Colette Grinevald, René Lacroix and Dejan Matić for inspiring comments on previous versions of this paper. I am also grateful to the patience and helpfulness of the Laz speakers in the region of Ardeşen and in Germany, who have supported my work for several years now.
}

Linguistic Discovery 9.2:49-77 
case marking system and argument linking rules (cf. Kutscher 2001, chapter 5). While all other dialects of Laz have case marking relating to syntactic relations of core arguments (ergative, nominative/absolutive, dative), Ardeșen-Laz does not case-mark core arguments, cf. (4) below.

Laz is basically an SOV language, exhibiting the categories case and number in nominal expressions and a rich inventory of verbal categories with up to eight different morphological slots to be filled in the predicate, cf. table 1.

\begin{tabular}{|l|l|l|l|l|l|l|l|}
\hline A & B & C & D & E & F & G & H \\
\hline NEG/MOD- & preverb- & $\begin{array}{l}1 / 2 \text { person- } \\
\text { (A or U) }\end{array}$ & $\begin{array}{l}\text { version vowel- } \\
\text { (voice, } \\
\text { applicative) }\end{array}$ & root- & CAUS- & TAM+P- & number \\
\hline
\end{tabular}

Table 1: Template for Inflectional Categories of the Verb in Laz

An example of an inflected verb form is given in (1).

(1) varelebuxedit

var-ele-b-u-xed-i-t

A-B-C-D-E-G-H

NEG-beside-1A-VV-sit-PAST.PFV+non-3rdA-PL

'We did not sit beside him/her/it.'

As table 1 and example (1) show, the information on person and number in Laz predicates is not marked by a single affix but rather results from the interaction of prefixes and suffixes. The latter are portmanteau forms coding tense/aspect/mood and person simultaneously (cf. Mattissen 1995). Concerning the person marking in the predicate, Laz exhibits a characteristic asymmetry. Only $1^{\text {st }}$ person and $3^{\text {rd }}$ person actors as well as $1^{\text {st }}$ person and $2^{\text {nd }}$ person undergoers are marked on the predicate, $2^{\text {nd }}$ person actors and $3^{\text {rd }}$ person undergoers are unmarked but can be deduced paradigmatically. Disregarding this asymmetry in the inflectional paradigm, predicates in Laz are head marking, with up to two arguments being represented in the verbal inflection, i.e. depending on the valence of the verb, verbal inflection is mono- or polypersonal. With polypersonal verbs the finite verb inflects for both actor and undergoer, cf. (2). ${ }^{2}$

\section{(2) ce-k-çare}

PRV-2U-beat:[1>2]SG:FUT.PFV ${ }^{3}$

'I will beat you!'

In contrast to its sister varieties, Ardeşen-Laz is an active language (Klimov 1974), i.e. monopersonal verbs subdivide into two classes, depending on whether the verb takes a controlling or non-controlling single core argument (also called semantic alignment system, cf. Donohue \& Wichmann (eds.) 2008). Controlling single core arguments are marked as actor on the predicate, cf. the first person marker $b$ - in (3a). Non-controlling single core arguments are

\footnotetext{
${ }^{2}$ Examples of my own data are written in the Lazoğlu/Feurstein-alphabet introduced to the Laz community in Turkey in 1984. It deviates from the Caucasianists' transcription in the following graphemes $(<\mathrm{Laz}=$ Caucasianist $>$ ): $\langle c ̧=\check{c}\rangle,\left\langle\breve{c}=\check{c}^{\prime}\right\rangle,\langle c=\breve{j}\rangle,\left\langle\check{k}=k^{\prime}\right\rangle,\left\langle\breve{p}=p^{\prime}\right\rangle,\langle s ̧=\breve{s}\rangle,\left\langle\breve{t}=t^{\prime}\right\rangle,\langle 3=c\rangle,\left\langle\breve{s}=c^{\prime}\right\rangle$. For cited data from other sources the original transcription and glossing has been kept.

${ }^{3}$ Polypersonal inflecting verbs are marked for two arguments. In the glosses this is represented by an angled bracket ">", which indicates that an actor (A) is acting on an undergoer (U).
} 
marked as undergoer, cf. the first person marker $m$ - in (3b). See also Kutscher (2009: 116f.) for further discussion.

(3a) b-ulur

1A-go:SG:PRS

'I go.'

(3b) m-a-çinden

1U-VV-sneeze:SG:PRS

'I sneeze.'

While most Laz dialects have argument marking (nominative/absolutive, ergative, dative) as well as adjunct marking cases (cf. Holisky 1991), in the dialect of Ardeșen argument-NPs are always unmarked for case, cf. (4). This holds for the actors of polypersonal predicates (4a, 4b), primary and secondary objects (in the sense of Dryer 1986), cf. (4b), and for the single core argument of monopersonal active and inactive predicates $(4 \mathrm{c})$.

(4a) nana çay žiluy

mother tea pluck:[3>3]SG:PRS

'Mother plucks tea.'

(4b) oyretmeni bere kitabi me-çay

teacher child book thither-give:[3>3]SG:PRS

'The teacher gives the book to the child.'

$\begin{array}{lll}\text { (4c) biç̧i trayuduy } & \text { / } & \text { biçi aş̌̌rurinen } \\ \text { boy sing:3A:SG:PRS } & & \text { boy VV-be.afraid:3U:SG:PRS } \\ \text { 'The boy sings.' } & \text { 'The boy is afraid.' }\end{array}$

The case system in Ardeşen-Laz is restricted to mark adjunct phrases, such as instrumentals (-te 'INS', cf. (5a)), comitatives (-şǩala 'COM'), benefactives (-şeni 'BEN', cf. (5b)), goals and sources (-şa 'MOT). See Kutscher (2001, chapter 5) for a detailed discussion of the case system in Ardeşen-Laz.

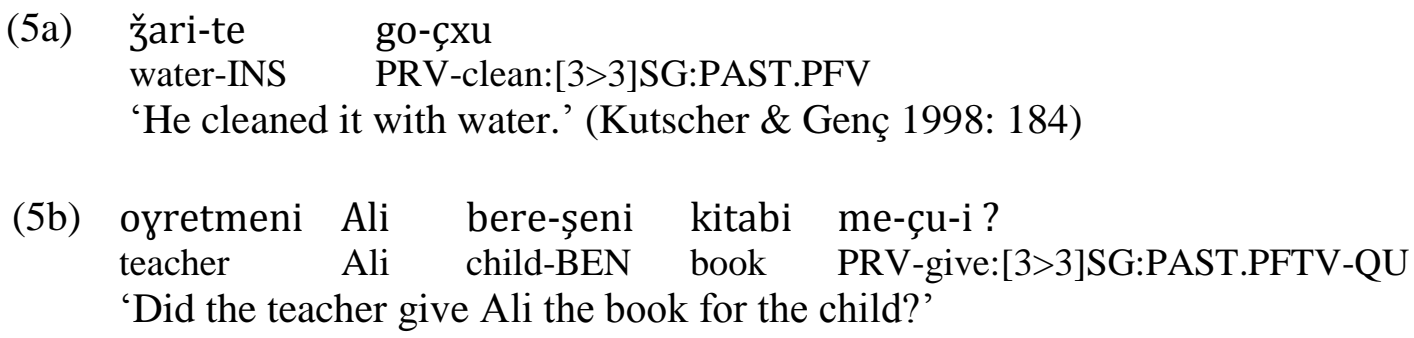

As can be seen in (5), the core arguments of the verb mepçam 'give' are all unmarked for case while in contrast the beneficient of the giving event, the child, is marked by the benefactive case marker -şeni 'BEN'. However, time and locative adjuncts are unmarked for case as well, cf. (6). 
(6) livadi $\breve{\text { p}}$-trayudum

garden 1A-sing:SG:PRS

'I sing in the garden.'

Hence, third arguments (e.g. kitabi 'book' in (4b, 5b)) and time and locative adjuncts cannot formally be distinguished but can only be differentiated on semantic grounds.

Expressions of spatial relations frequently have a verbal predicate prefixed by a preverb with spatial semantics. In these cases, the ground-NP of the spatial expression is always unmarked for case in static and in directional expressions, cf. section 3.2. and Kutscher (2010). Since a spatial preverb has a two-place argument structure relating to the figure and the ground of a spatial configuration (Lehmann 1983: 147f; Craig \& Hale 1988), we can thus conclude that ground-NPs unmarked for case are core arguments of the predicate. Since ground-NPs most commonly are non-speech-act participants, in most cases one cannot decide whether a ground-NP is a second or third argument.

\section{Basic Spatial Constructions in Ardeșen-Laz}

Basic Spatial Constructions ${ }^{4}$ in Ardeșen-Laz, i.e. the construction which is given as discoursepragmatically unmarked answer to the question "where is X?" in the case of static spatial scenes and the one which is given to the question "where to/from where is X moving/being moved?" in the case of dynamic spatial scenes are constructed as containing three constituents: a NP referring to the entity being located (the figure), a NP referring to the place in which the figure is located or moved to or from (the ground) and a predicate which forms part of a morphological complex structure containing an inflected verb relating to the spatial orientation and shape characteristics of the figure (the spatial verb) together with a preverb giving spatial information about the configuration between figure and ground (the spatial relator). In the following sections, I will give a brief overview on the spatial semantics of the verbal root and its lexicalisation patterns (3.1) followed by some remarks on the spatial cases found in Laz, with a focus on the Motative case, a directional-ablative case which is only found in the Ardeşen variety of Laz (section 3.2) and an introductory overview on the preverbs in Laz (section 3.3). In section 4, I will then discuss the system of spatial preverbs in more detail, with a focus on the semantics of spatial preverbs which are used in expressions referring to topological spatial relations between figure and ground.

\subsection{Lexicalisation Patterns of Spatial Verbs in Laz}

In Ardeşen-Laz, information on spatial relations is mainly coded in the verbal complex, whereby the coding is divided among two subparts of the verbal complex, the preverb and the verb root. The spatial information given by the preverb focuses mainly on the axial orientation and the shape of the ground referent, while the verb root focuses on physical features of the figure (e.g. shape, consistency, etc.). Hence, for expressions of motion, the verb root codes motion and manner of motion and the preverb codes the path information, cf. (7). With respect to the

\footnotetext{
${ }^{4}$ The term Basic Spatial Construction is based on the term Basic Locative Construction as used by Levinson (2000), Levinson \& Wilkins (eds.) (2006).
} 
typology of motion verbs introduced by Talmy $(1985,2007)$, Laz thus uses the satellite-framed strategy, cf. schema in (8).

(7) feluǩa mayara meş̌̌imçiy

feluǩa mayara meş̌̌a-i-mçiy

boat cave in-VV-swim:3A:SG:PRS

'The boat floats in(to) the cave.'

(8) schematic:

[relator motion/manner+TAM+P $]_{\text {spatial configuration }}$

PRV- $\quad$ verbroot+inflection

With respect to stance expressions, Laz is a multiverb type language (type II of the Ameka \& Levinson 2007 locative verb typology), i.e. the positional verbs form a larger set of verbs expressing spatial dispositions of figures with respect to specific properties of the figure referent such as geometric properties, canonical vs. non-canonical orientation, single vs. aggregate, etc. (cf. Kutscher \& Genç 2007). For instance, the positional verb byun denotes the configuration of a figure which is conceptualized as an aggregate of entities, such as beans (9a), as opposed to PRV-zun, which is used with non-aggregate like figures which lack a canonical orientation (9b) and PRV-dgun which is used with non-aggregate like figures that have a canonical vertical orientation $(9 \mathrm{c})$.

(9a) lobca masa goo-byun

beans table on-aggregate:3A:SG:PRS

'The beans are spread on the table.'

(PSPV 25 )

(9b) biga masa goo-zun

stick table on-lie:3A:SG:PRS

'The stick is (lying) on the table.'

(PSPV 17)

(9c) tasi masa goo-dgun

bowl table on-stand:3A:SG:PRS

'The bowl is (standing) on the table.'

In sum, we can state that with respect to the lexical properties of the verb roots, Laz is a rather ordinary language, fitting well into the attested typological patterns of spatial verbs of stance and motion. As the following sections will show, with respect to the semantics of its spatial case system and the semantics of the spatial preverbs, Laz is typologically rather unusual.

\subsection{Spatial Case(s)}

Spatial expressions differ in construction with respect to whether the spatial configurations they refer to are static or dynamic. With static spatial expressions the ground-NP is unmarked for case while in dynamic spatial expressions the ground may be marked with the motative case. The following examples give the two constructional schemes together with some language examples. 
$\underline{\text { Static spatial expressions }}$

The construction scheme of a static spatial expression in Ardeşen-Laz is given in (10).

(10)

$\begin{array}{llll}\text { figure } & \text { ground } & \text { [relator } & \text { manner+TAM+P }]_{\text {spatial configuration }} \\ \text { NP } & \text { NP } & \text { PRV- } & \text { verbroot+inflection } \\ \text { şișe } & \text { masa } & \text { goo- } & \text { dgun } \\ \text { bottle } & \text { table } & \text { on } & \text { stand:3A:SG:PRS }\end{array}$

(PSPV 37)

As is evident from the example in (10), the Laz variety under scrutiny in this paper clearly has no morphological marking of the ground-NP which expresses the semantic role of place whatsoever. It is neither marked by case nor do we find adpositional marking in the phrase relating to the ground.

In other varieties of Laz, the semantic role of place is marked with the DAT-case affix, cf. (11) (see also Holisky 1991: 409; Lacroix 2009).

(11) Vitse-Arǩabi (Fındıklı):

A msk'fa bozo kojiroms ham oxori-s

A pretty girl he.sees this house-DAT

'He sees a pretty girl in that house.' (Anderson 1963: 113)

cp. Ardeșen:

$\begin{array}{lllll}\text { ham oxori a msǩva bozomota } & \text { a-ziren } \\ \text { DEM house } & \text { one pretty } & \text { girl } & \text { VV-see:3A:SG:PRS }\end{array}$

'He sees a pretty girl in that house.'

Dynamic spatial expressions

In dynamic spatial expressions in Ardeşen-Laz the ground-NP may be marked by the so-called motative case, cf. (12). ${ }^{5}$

\begin{tabular}{|c|c|c|c|}
\hline figure & ground-case & [relator & manner+TAMP $]_{\text {spatial configuration }}$ \\
\hline NP & NP & PRV & verbroot+inflection \\
\hline $\begin{array}{l}\text { șişe } \\
\text { bottle }\end{array}$ & $\begin{array}{l}\text { masa-şa } \\
\text { table-MOT }\end{array}$ & $\begin{array}{l}e- \\
\text { up }\end{array}$ & $\begin{array}{l}\breve{p} \text {-с̆орum } \\
\text { 1A-take:[1>3]SG:PRS }\end{array}$ \\
\hline
\end{tabular}

The term motative originates in a grammatical sketch on Laz written by Rosen (1844) and captures the particular semantics of this case, which only encodes that the referent of a figure nominal moves in relation to the motative-marked ground-nominal. The meaning of the motative is vague with respect to whether the figure is moving towards a goal, as in (13a), or moves away from a source, as in (13b). The direction of motion is usually specified by a spatial prefix to the predicate, e.g amo- 'into' in (13a) or gamo- 'out of' in (13b) or by inference from information given in the verb root and following from properties of the figure and ground referents.

\footnotetext{
${ }^{5}$ The ground is not obligatorily marked with a case marker. The presence of the case marker is conditioned by the characteristics of the spatial relator as well as the verb stem and by discourse-pragmatics. If a dynamic spatial expression does only exhibit a simplex verb, i.e. a verb that does not have a preverb, then the use of the motative case is obligatory. With verbs of motion and caused motion that contain a preverb the use of the motative is more complex (for details, cf. Kutscher 2010).
} 
$\begin{array}{lll}\text { (13a) bere } & \text { oxori-şa } & \text { am-ulun } \\ \text { child } & \text { house-MOT } & \text { PRV-go:3A:SG:PRS }\end{array}$

'The child goes inside the house.'

(13b) bere oxori-şa gam-ulun

child house-MOT PRV-go:3A:SG:PRS

'The child goes out of the house.'

This kind of conflation of the allative with the ablative meaning seems to be typologically rather exceptional, since it has never been reported before and sometimes has even been ruled out as a cognitive possibility (Andrews 1985, Ikegami 1987, Stolz 1992, Creissels 2006). Considering the fact that motion towards a ground and motion away from a ground are spatial events which are in opposition to each other and exclude each other semantically, the allative-ablative conflation seems to be in conflict with a universal cognitive principle leading to a conceptual bias for goal paths and a focus of attention more on the endpoint than on the starting point of a motion event (e.g. Andrews 1985, Regier 1996, Regier \& Zheng 2007, Lakusta \& Landau 2005, Ihara \& Fujita 2000). But Kutscher (2010) argues that the semantics of the motative fit with this cognitive principle.

In the other Laz varieties, goal and source marking is distributed among two discrete cases. For goal-directed configurations the ground is marked by the allative case marker -şa/-şe (14a, 14c) whereas in source-directed configurations the source-NP is marked by the ablative case marker -şen (14b, 14c), cf. also Holisky (1991), Lacroix (2009). As reported by Lacroix (2009:704), in some constructions marking of the ground by the same case as used in static location (dative) is also possible.

(14) Vitse-Arǩabi (Fındıklı):

$\begin{array}{lll}\text { (14a) Ali } & \text { Vice-še } & \text { komulun } \\ \text { Ali } & \text { Vitse-to } & \text { comes }\end{array}$

'Ali comes to Vitse.' (Anderson 1963: 111)

(14b) Poli-šen Turani

Istanbul-from Turhan

'Turhan from Istanbul.' Anderson (1963: 110)

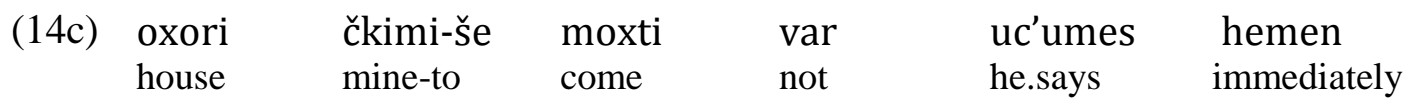

iani muši-šen igzalas

side his-from he.goes

'He (Turhan) doesn't say, "Come to my house!” Immediately he (Ali) goes away from him.' (Anderson 1963: 117)

As is shown in (14), in other Laz dialects there are two separate cases for goal- (-şa/-şe) and source-directed (-şen) spatial relations, which are comparatively close in phonological form. The exceptional case of Ardeşen-Laz might be a result of a phonetically motivated syncretism of the 
two forms into one. Note that the motative case has been reported on by Rosen in (1844). In the middle of the $19^{\text {th }}$ century, Laz was a striving language with a high amount of monolingual Laz speakers. Hence, the development of this case and its unusual semantics cannot be related to "the state of possible obsolescence of the language" at present as one reviewer suggested.

\subsection{Spatial Preverbs}

Ardeşen-Laz has 27 spatial preverbs which cover both the directional/locational as well as the deictic domain. Table 2 gives an overview of these preverbs. Note that two preverbs (mola- 'in; hither.along', gola- 'on, thither.along') are listed twice, i.e. in both columns of the table, since in dynamic spatial expressions, they have two distinct readings, depending on the verb semantics (deictic with verbs of motion, topological with verbs of caused motion).

\begin{tabular}{|c|c|c|c|}
\hline \multicolumn{2}{|c|}{ directional domain } & \multicolumn{2}{|c|}{ deictic domain } \\
\hline \multicolumn{2}{|c|}{ non-projective/topological } & \multicolumn{2}{|l|}{$\underline{\text { deictic }}$} \\
\hline \multirow{2}{*}{$\begin{array}{l}\text { ama- } \\
\text { ce- } \\
\text { cela- } \\
\text { ceș̌ka- } \\
\text { dolo- }\end{array}$} & \multirow{3}{*}{$\begin{array}{l}\text { 'into' } \\
\text { 'steep.down, on(to), in(to)' } \\
\text { 'sidewards.down, on(to)' } \\
\text { 'down.into.amidst' } \\
\text { 'in(to), down.through, } \\
\text { down.along' } \\
\text { 'steep up' } \\
\text { 'sidewards.up, besides' } \\
\text { 'up.(through).amidst' } \\
\text { 'out of' } \\
\text { 'on(to) 1D' } \\
\text { 'on(to)' } \\
\text { 'in, out.of' } \\
\text { 'in(to).(through).amidst' } \\
\text { 'in(to)' }\end{array}$} & $\begin{array}{l}\text { me- } \\
\text { mo- }\end{array}$ & $\begin{array}{l}\text { 'thither' } \\
\text { 'hither; "belonging.to", }\end{array}$ \\
\hline & & \multicolumn{2}{|c|}{ deictic+directional } \\
\hline $\begin{array}{l}\text { dolo- } \\
\text { e- } \\
\text { ela- } \\
\text { eş̌̌a- } \\
\text { gama- } \\
\text { gola- } \\
\text { goo- } \\
\text { mele- } \\
\text { meşǩ́a- } \\
\text { mola- }\end{array}$ & & \multirow[t]{9}{*}{$\begin{array}{l}\text { meo- } \\
\text { moo- } \\
\text { mola- } \\
\text { gola- } \\
\text { moǩo- }\end{array}$} & \multirow[t]{9}{*}{$\begin{array}{l}\text { 'across thither' } \\
\text { 'across hither, on.top.of } \\
\text { another.towards' } \\
\text { 'hither.along' } \\
\text { 'thither.along', } \\
\text { 'hither.asunder, hither."hook"' }\end{array}$} \\
\hline \multicolumn{2}{|l|}{$\underline{\text { circum }}$} & & \\
\hline go- & 'around' & & \\
\hline \multicolumn{2}{|c|}{ projective } & & \\
\hline $\begin{array}{l}e \check{k} a- \\
e \breve{a} a- \\
\check{k o z ̌ o-~}\end{array}$ & $\begin{array}{l}\text { 'behind' } \\
\text { 'under' } \\
\text { 'in(to) front, aside, over' }\end{array}$ & & \\
\hline \multicolumn{2}{|c|}{ more than one entity as $\mathrm{F}$ or $\mathrm{G}$} & & \\
\hline 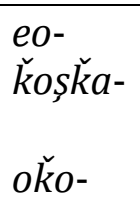 & $\begin{array}{l}\text { 'on(to).another' } \\
\text { 'heap-wise, into.one.another, } \\
\text { amidst' } \\
\text { 'asunder, together' }\end{array}$ & & \\
\hline \multicolumn{2}{|c|}{ non-transparent } & & \\
\hline$O X O-$ & 'accumulation?' & & \\
\hline
\end{tabular}


Most of the spatial preverbs exhibit certain morpho-phonological processes. In most cases, the final vowel changes systematically in interplay with the presence and absence of personal prefixes and the preroot vowel which serves several voice and applicative functions (version vowel, cf. Boeder 1968, Kutscher 2001, chapter 1; Kutscher 2009, chapter 6). Preverbal allomorphs may e.g. alternate between final vowel /a/ and /e/ or between final vowel /o/ and /a/ or between vowel and zero. The preverb me- alternates between /me/ and /n/. The morphophonological rules are complex, depending on the presence of personal prefix and the quality of the version vowel. Furthermore the rules differ with respect to the syllabicity of the preverb. Since the morpho-phonological details are not of relevance for the subject of this paper, I did not include them in the discussion.

Apart from this rather large set of spatial preverbs, Ardeşen-Laz has a small set of preverbs that serve mainly information structure functions, i.e. the preverbs $d o-$, $k o-$, mende- have speaker modality functions comparable to so-called focus particles (cf. also Mattissen 2001, Lacroix 2009).

Most of the preverbs used in descriptions of spatial scenes are not restricted to either dynamic or static spatial relations but rather are neutral in this respect, i.e. can be used in both kinds of expressions (15a, 15b).

zeytini yayi dolo-b-u-bi

olive oil PRV-1A-VV-pour:[1>3]SG:PAST.PFV

'I poured olive oil into (the cow's mouth).' (Kutscher \& Genç 1998:34)

(15b) şişe ťǩkina dolo-zun

bottle pannier PRV-lie:3A:SG:PRS

'The bottle is in the basket (lit.: pannier).'

(PSPV 22)

A minority of preverbs, however, are restricted to expressions of dynamic spatial scenes. These are: ama- 'into', gama- 'out.of', meo- 'thither.across', moo- 'hither.across', mořo'hither.asunder', e-'up', eş̌k - 'up.amidst', ceş̌ka- 'down.amidst'.

In sum, all spatial preverbs in Laz allow for use in descriptions of dynamic spatial scenes, and the majority of the preverbs can be used in descriptions of static spatial scenes as well. The set and function of both kinds of preverbs so far seem to be congruent to other Laz dialects (cf. Holisky 1991, Lacroix 2009).

Section 4 will focus on describing the semantics of the preverbs that can be used to denote topological spatial configurations. This subpart of the preverb system in Laz is complex with respect to its semantic structuring and from the point of view of semantic typology it is rather unusual as will become clear from the following discussion.

\section{The Use of Laz Preverbs in Descriptions of Topological Spatial Scenes}

In order to analyze the inventory and semantics of the preverbs which are used to express topological spatial configurations, the visual stimuli developed by the Language and Cognition Group of the Max Planck Institute Nijmegen were used, namely the Topological Relations Picture Series (TRPS) and the Picture Series for Positional Verbs (PSPV). These have been complemented by other stimuli when necessary. The stimuli show two or more entities in spatial 
relation to one another which geometrically speaking are configurations of inclusion, surface contact and circumvention and which functionally are containment and support relations. As a result of these elicitations, we find that 11 different preverbs are used in Laz for describing these spatial scenes. For a first step in analysis, in the following the preverbs are ordered into two types of spatial domains, the IN-domain (cf. section 4.1) where the figure-referent is fully or partly contained in the ground-referent and the ON-domain, where the figure-referent is in a surface contact relation to the ground-referent (cf. section 4.2). This includes circumventional relations, where the figure-referent extends in a circular relation around the surface of the ground-referent (cf. section 4.4). For an overview of the preverbs to be discussed cf. table 3.

\begin{tabular}{|c|c|}
\hline IN-configurations: & ce-, dolo-, meş̌̌ \\
\hline \multicolumn{2}{|l|}{ ON-configurations: } \\
\hline PLANAR & cela-, goo-, gola-, eo-, me- \\
\hline CIRCUMVENT & $\mathrm{go}^{-}, \mathrm{mo-}$ \\
\hline
\end{tabular}

As will become clear in the following analysis of the use of these 11 preverbs, the ordering according to geometrically defined parameters as presented in table 3 does not fully reflect the categorization principles which underlie the Laz system of spatial preverbs. It will become clear in the discussion of the data that conceptual parameters of a different quality have to be taken into account.

\subsection{IN-Relations}

When comparing the differences in use between ce-, dolo-, meş̌k shape properties of the ground referent are relevant factors for the choice of the preverb. Dolo- is used to refer to topological spatial configurations in which the ground has an opening that is smaller than the vertical extension of the ground-referent, i.e. in which the ground referent resembles a (vertically oriented) cylinder. This kind of shape can be found e.g. with panniers, which are the prototypical baskets in the Laz culture (16a). But also bottle necks have this kind of shape (16b). Both configurations can only be referred to by the preverb dolo-.

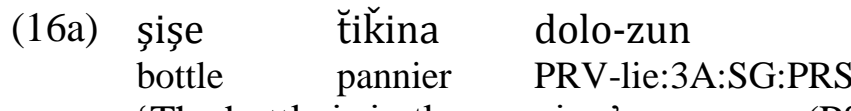

'The bottle is in the pannier.' $\quad$ (PSPV 22)

$\begin{array}{lll}\text { (16b) mantari } & \text { şişe } & \text { dolv-o-nzoy } \\ \text { cork } & \text { bottle } & \text { PRV-VV-be.stuck:3A:SG:PRS }\end{array}$

'The cork is stuck in the bottle.'

(TRPS 62)

In contrast, containers that have a broad opening and a flat vertical extension like bowls (17a) or beds (17b) trigger the use of the preverb $c e$-.

$$
\begin{array}{lll}
\text { oşǩuri } & \text { tasi } & \text { ce-zun } \\
\text { apple } & \text { bowl } & \text { PRV-lie:3A:SG:PRS }
\end{array}
$$

'The apple is in the bowl.'

(TRPS 2) 


$$
\begin{aligned}
& \text { bere yatayi ce-zun } \\
& \text { child bed PRV-lie:3A:SG:PRS } \\
& \text { 'The child is in the bed.' }
\end{aligned}
$$

The preverb meş̌k respect to the figure, like a hole in a tree (18a), or if the ground-referent is dense or filled with some material, e.g. a haystack (18b).

(18a) Ǩinçi mca meş̌a-xen
bird tree PRV-sit:3A:SG:PRS
'The bird is in the (hollow) tree (trunk).'
(TRPS 67)

nçala bardi meş̌̌a-xedu, hay.stack PRV-sit:3A:SG:PAST.PFV

va-gam-ulun

NEG-PRV-go:3A:SG:PRS

'(The man) hid, he sat in the hay stack, he did not come out of it.' (Kutscher \& Genç 1998: 155)

In order to fully understand the semantics of the preverbs, we furthermore have to observe the usage of the preverbs in descriptions of dynamic spatial scenes. For all of the preverbs used in descriptions of IN-configurations (and in fact for all preverbs used in descriptions of spatial scenes), the orientation of the motion path of the figure according to the vertical and horizontal axes is relevant (axial orientation). Let us first have a look at the use of the respective preverbs in descriptions of dynamic spatial scenes.

Use of meşka-, mola-, dolo- and ce-in descriptions of dynamic spatial scenes

For the use of the preverb the horizontal axis of the motion path of the figure is relevant. The

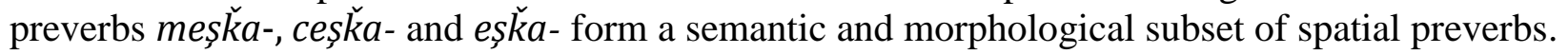
All three refer to spatial scenes with dense grounds differing only with respect to the axial

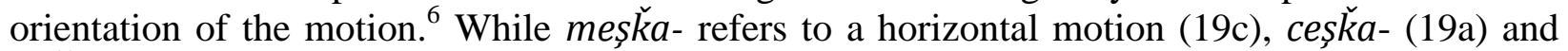
eşka- (19b) refer to motion along the vertical axis.

ceş̌̌e-b-ulur

PRV-1A-go:SG:PRS

'I go down (e.g. in a mountain forest, through the brushwood)'

(19b) eş̌ke-b-ulur

PRV-1A-go:SG:PRS

'I go up (e.g in a mountain forest, through the brushwood)'

\footnotetext{
${ }^{6}$ With respect to their morphological form we can see that all three preverbs do not only share a common semantic feature ([dense]/[narrow], [amidst]) but also share some phonological material. Although the final part of the preverbs, /ş̌ka/, is not productive and cannot be used independently from these preverbs to express density or narrowness, it may well be that diachronically it served as a morpheme of its own. In modern Laz there is still a noun ş̌ka 'waist' and another noun derived from this body part term oş̌kena 'middle of something'.
} 
(19c) meş̌̌e-b-ulur

PRV-1A-go:SG:PRS

'I go horizontally (e.g. in a forest, through the brushwood)'

The preverb mola- is used for dynamic spatial scenes in which the figure moves or is moved into a ground horizontally. It does not include any further specific information about the properties of the ground referent in contrast to meşka- ([dense, narrow], cf. 19c). The preverb mola- contrasts with the preverb dolo- with respect to the axial orientation of the motion path of the figure. This difference in meaning is illustrated with the data in (20). For pouring a liquid into a container which is oriented vertically, such as the neck of a cow which is lying on the earth (or a pannier, cf. (16a) above) the preverb dolo- is used (20a). For pouring liquid in the mouth of a person standing, i.e. where the liquid is poured horizontally, the preverb mola- is used, cf. (20b).

(20a) zeytini yayi dolo-b-u-bi

olive oil PRV-1A-VV-pour:[1>3]SG:PAST.PFV

'I poured olive oil into (the cow's mouth).' [the cow is lying on the ground] (Kutscher \& Genç 1998:34)

(20b) ̆ici క̌ari molo-b-i-bi

mouth water PRV-1A-VV-pour:SG:PAST.PFV

'I put water in my mouth.' [in order to spray it on swarming bees] (Kutscher \& Genç 1998:40)

The fact that horizontal orientation of the figure's path is relevant for the choice of mola-can also be illustrated by the use of the preverb mola- with verbs of motion. In this case, the preverb expresses that the figure (i.e. the agent of the motion event) moves on a horizontal path towards the deictic center, cf. (21). The plantation called Merze is on the same height in the mountains as the home of the narrator of the story of which the introductory line is given in the example in (21).

$$
\begin{array}{lccc}
\text { şimdi } & \text { andya } & \text { Merze-şa } & \text { ko-mola-ftitu } \\
\text { well } & \text { one.day } & \text { Merze-MOT } & \text { MOD-PRV-1A:go:PL:PAST.PFV } \\
\text { 'Well, one day we came home from Merze.' (Kutscher \& Genç 1998: 149) }
\end{array}
$$

Use of meșka-, mola-, dolo- and ce-in descriptions of static spatial scenes

As alluded to above, the parameter of axial orientation is even relevant when the preverbs in question are used in descriptions of static spatial scenes. The choice of the preverb depends on the axial orientation of the path on which the figure is thought to move in order to become located in the stasis configuration which is described by the expression in question. Hence, in descriptions of static spatial scenes the preverb refers to the path which was covered by the figure on its way to the ground. Thus, the static spatial configuration is inferred by the hearer rather than expressed by the preverb. I will illustrate this conclusion by opposing the preverbs mola-, dolo- and ce- in the following paragraphs.

The preverb $c e$ - is used for topological configurations in which the figure has been placed into the container by way of a vertical motion, e.g. in cases where the opening of the container is 
on the upper region of the ground-referent. For instance, an apple is placed into a bowl from above, therefore the preverb ce- is used for describing the topological configuration described in (17) above, while a cup is placed into a cupboard with moving it along a horizontal path. Therefore, the preverb mola- is chosen for describing the topological configuration in (22), while the preverb ce-cannot be used.

$\begin{array}{lll}\text { fincani dolabi mola-dgun } & \text { *ce- } \\ \text { cup cupboard PRV-stand:3A:SG:PRS } & \\ \text { 'The cup is in the cupboard.' }\end{array}$

Furthermore, for the use of the preverb ce- the opening of the container need not necessarily be on the upper side of the ground referent, but may also be at the side of the ground referent, like a door on a car, as the following example (23) illustrates. For this kind of configuration, the preverb mola- cannot be used.

$\begin{array}{lll}\text { oxorza } \quad \text { araba } & \text { ce-xen } & \text { *mola- } \\ \text { woman car } & \text { PRV-sit:3A:SG:PRS } \\ \text { 'The woman sits in the car.' } & \end{array}$

The difference between the configuration in (22) and (23) lies in the axial orientation of the path along which the figure moves or is moved to reach its final location. Whereas entities that move into or are being moved into a cupboard or a house cover a more or less horizontal path, a person which sits down in a car moves along a vertical axis (i.e. from standing to sitting). This finding supports the conclusion that the path which is covered by the figure is the relevant factor and not some shape property of the ground-referent.

The data in (21) above also illustrate that the use of the preverb mola- is not restricted to configurations which geometrically are configurations of partial or complete inclusion. For the use of the preverb the parameter of axial orientation of the motion path of the figure is relevant and not whether or not the figure is included in the ground. This holds also for the preverb dolo-, cf. (24).

$\begin{array}{lllll}\text { dunya } & \text { usti başi } & \text { şǩimi } & \text { mca } & \text { do-b-i-i } \\ \text { all } & \text { clothes } & \text { 1SG:POSS } & \text { milk } & \text { MOD-1A-VV-become:SG:PAST.PFV }\end{array}$

haşo dolo-m-a-oru

like.this PRV-1U-VV-flow:3A:SG:PAST.PFV

'My clothes were covered in milk. It ran all down me.' (Kutscher \& Genç 1998: 127f.)

Likewise, the preverb $c e$ - is not only used in descriptions of containment configurations, but is also used in descriptions of topological spatial scenes where the figure is in contact to the surface of the ground-referent, cf. (25).

$\begin{array}{lll}\text { (25a) masa } & \text { hali } & \text { ce-dgun } \\ \text { table } & \text { carpet } & \text { PRV-stand:3A:SG:PRS }\end{array}$

'The table is on the carpet.' 
(25b)
şeyi masa ce-zun
cloth table PRV-lie:3A:SG:PRS

'The piece of cloth is on the table.'

(PSPV 4)

Furthermore, topological spatial configurations which are related to a horizontally oriented surface can be referred to by the use of the preverb goo-. As (26) below illustrates, the preverb goo- is used in configurations of a figure which is in contact with a part of the surface of a ground-referent. In descriptions of spatial scenes in which the surface region of a ground referent is above ground-level, e.g. the surface of a table, the use of the preverb ce- exhibits some overlap with the use of the preverb goo-. For descriptions of this kind of configurations, I found that speakers did not uniquely choose the preverb ce-, but 2 out of 4 speakers preferred goo-for describing the configuration of a piece of table cloth lying on a table, cf. (26).

$$
\begin{array}{lll}
\text { şeyi } & \text { masa } & \text { goo-zun } \\
\text { cloth } & \text { table } & \text { PRV-lie:3A:SG:PRS }
\end{array}
$$

'The cloth is on the table.'

(PSPV 4)

In order to better understand the meaning and use of the preverb ce-, one has to take into consideration the fact that the preverb $\mathrm{ce}$ - is used for the description of vertically oriented dynamic spatial scenes. In cases where the figure-referent moves steeply downwards, e.g. a person on a ladder as in (27), the vertical downward motion of the figure is expressed by the preverb ce-.
mskala
me-m-i-du
ce-fti
ladder PRV-1U-VV-put:[3>1]SG:PRS
PRV-1A:go: SG:PAST.PFV
'She put the ladder (on the wall) for me (and) I went down.' (Kutscher \& Genç 1998:

83)

We can thus conclude that the relevant parameter for the use of the preverb $c e$ - in descriptions of topological spatial scenes is not the geometrical-functional parameter of inclusion/containment, but the parameter of axial orientation of the configuration with respect to the path the figure covered by being placed in relation to the ground. The spatial scenes for which the preverb $c e$ can be used to describe these configurations share the fact that the figure moves or is moved along a vertically oriented path in order to achieve its final static position. Whether the figure is in a containment or surface relation then follows from inferences based on world-knowledge.

Figure 1 summarizes the types of spatial configurations for which the preverb ce- is used and illustrates that the preverb ce-comprises ON, IN as well as DOWNWARD geometrical configurations. 


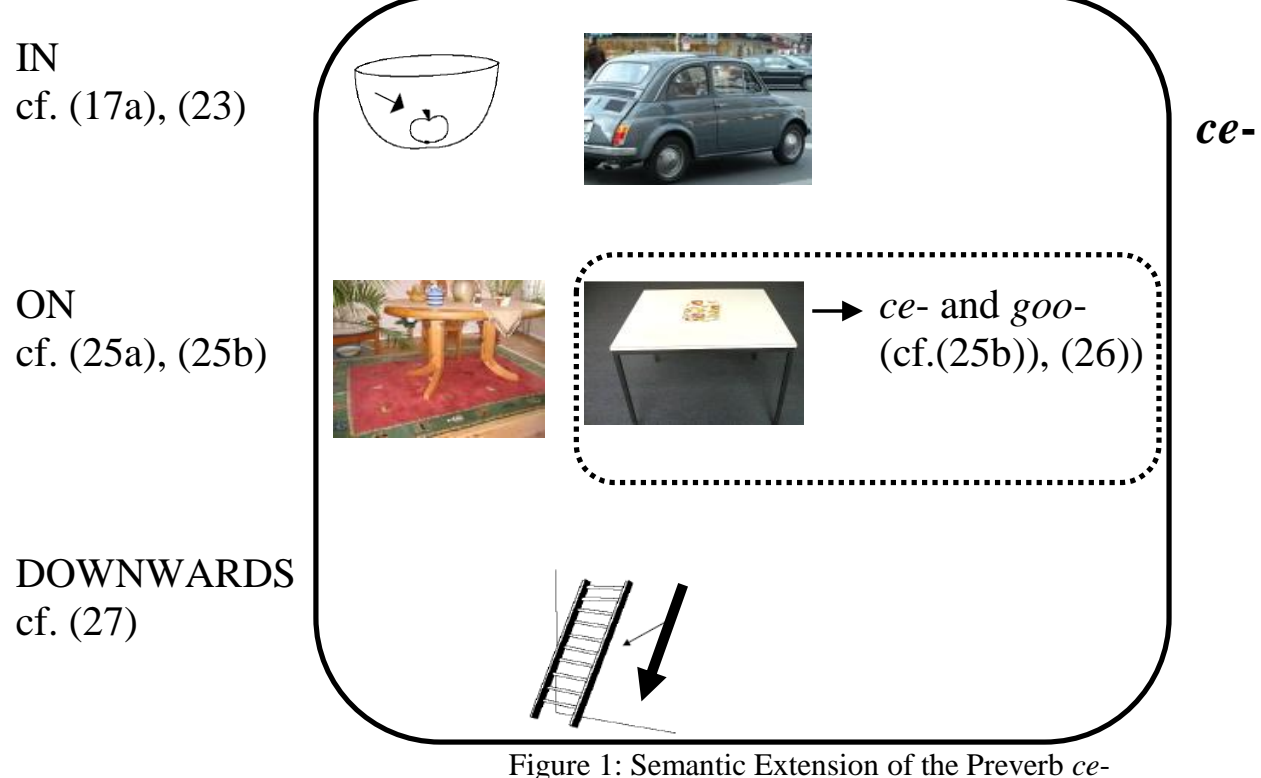

\subsection{ON-Relations}

When comparing the differences in use between goo-, gola-, cela- and me-, we find that for these preverbs the same two parameters, shape properties of the ground and axial orientation of the figure's path, are decisive factors for the choice of the preverb. As illustrated in (28a) and (26) above, the preverb goo- is used in configurations of a figure which is in contact with a part of the surface of a ground-referent. Additionally, as the comparison with the use of the preverb me- in (28b) shows, the surface of the ground is horizontally oriented, whereas for vertical (28b), (28c) and non-oriented configurations $(28 \mathrm{~d})$ the preverb $m e$ - is chosen.

(28a) fincani masa goo-dgun

cup table PRV-stand:3A:SG:PRS

'The cup is on the table.'

(TRPS 1)

(28b) mskala Ǩoda me-zun

ladder wall PRV-lie:3A:SG:PRS

'The ladder is leaning on the wall.' (lying along a wall: ela-zun)

(TRPS 58)

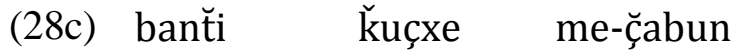

band.aid leg PRV-stick.to:3A:SG:PRS

'The band aid is on the leg.'

(TRPS 35)

$\begin{array}{lll}\text { (28d) pekmezi } & \text { xami } & \text { n-u-sun } \\ \text { jam } & \text { knife } & \text { PRV-VV-be.smeared:3A:SG:PRS }\end{array}$

'The jam is smeared on the knife.'

(TRPS 12)

We also find that shape properties of the ground are relevant for the choice of preverbs in expressions of topological surface configurations. Like the preverb goo-, the preverb gola- is restricted to configurations in which the contact region of the ground is horizontally oriented. 
Additionally, however, the region of the ground-referent with which the figure is in contact has a prominent 1-dimensional extension, such as a shelf, cf. (29).

$\begin{array}{lll}\text { çitabi } & \text { ožude } & \text { gola-zun } \\ \text { book } & \text { shelf } & \text { PRV-lie/stand:3A:SG:PRS }\end{array}$

'The book is on the shelf.'

(TRPS 8)

For configurations where the prominent 1-dimensional extension of the spatial region is oriented vertically, the preverb cela- is used, cf. (30).

$\begin{array}{lll}\text { rezimi } & \text { koda } & \text { cela-bun } \\ \text { picture } & \text { wall } & \text { PRV-hang:3A:SG:PRS }\end{array}$

'The picture is on the wall.'

(TRPS 44)

(30b) patto aski cela-bun jacket hook down-hang:3A:SG:PRS

'The jacket is attached (lit.: hangs down from) to the hook.'

(TRPS 9)

Besides describing certain topological scenes, the preverb is also chosen in descriptions of dynamic spatial scenes. In these cases it is used to describe downward motions on 1-dimensional ground-regions such as paths or roads in the mountains, cf. (31).

(31) cele-b-ulur

PRV-1A-go:SG:PRS

'I go down a road/path (e.g. in the mountains)'

For upward motions on paths and roads, the preverb ela- is used, cf. (32a), while a horizontal motion is referred to by the preverb gola- (32b).

(32a) ele-b-ulur

PRV-1A-go:SG:PRS

'I go up a road/path (e.g. in the mountains)'

(32b) golo-b-ulur

PRV-1A-go:SG:PRS

'I go along a horizontally oriented road or path'

Unlike the preverb mola- mentioned above in (21), the preverb gola-does not have a deictic component. The horizontal motion in (32b) is not related to a deictic center, whereas the motion in (21) above is directed towards the deictic center.

A problematic case for the analysis of the use of the preverb cela- is the one presented in (33).

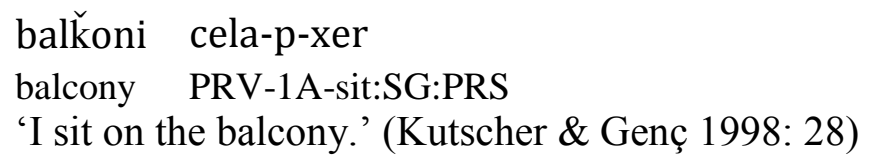


This case seems problematic because the surface region of the ground-referent is oriented horizontally and thus one might expect that speakers choose the preverb goo-.

In my data, there is also one speaker who chooses cela- instead of goo- to describe a scene in which a stick is lying on a table. The spatial scene in question shows a stick lying at the edge of the table, aligned to its rim, cf. (34).

biga masa cela-zun
stick table PRV-lie:3A:SG:PRS
'The stick is lying on the table (aligned with the rim of the table).'

What configurations like (33) and (34) have in common is that the spatial region relevant for the conceptualisation of the topological configuration is an edge, i.e. a 1-dimensional region at the rim of the upper region of the ground-referent. Maybe the choice of the preverb cela- is caused by the fact that cela- - when used in descriptions of dynamic spatial scenes - is restricted to downward motions along a path or road, cf. (31). In order to gain a better insight in the meaning and range of use for cela- more data have to be collected in future research.

In sum, we can conclude that the feature of 1-dimensionality of the spatial region of the ground is relevant for the use of the preverbs gola- and cela- as well as its orientation with respect to the vertical or horizontal axis. ${ }^{7}$

In my data, there is one more preverb which is used in descriptions of topological spatial scenes, the preverb eo-. The analysis for the range and meaning of use of this preverb is, however, at the moment rather preliminary and needs further investigation. For the moment, it can be stated that the preverb eo- is chosen in cases where the ground conceptually consists of more than one object, i.e. when something is placed on top of a stack as in (35a). For some speakers it is also possible to choose the preverb for configurations of multiple entities being placed on a horizontal surface (35b) or when the figure itself forms a stack as the folded cloth in (35c). Since some speakers find the use of goo- acceptable for (35b) and (35c) there seems to be a semantic overlap between the preverbs eo- and goo-.

$$
\begin{aligned}
& \text { yufka eo-b-o-dum } \\
& \text { puff.pastry PRV-1A-VV-put:[1>3]SG:PRS } \\
& \text { 'I put layers of puff pastry one upon the other.' }
\end{aligned}
$$

$$
\begin{aligned}
& \text { tope-pe masa eo-zunan } \\
& \text { ball-PL table PRV-lie:3A:PL:PRS } \\
& \text { 'The balls are (lit.: are lying) on the table.' }
\end{aligned}
$$

(PSPV 8)

\footnotetext{
${ }^{7}$ It may as well be argued that this also has its repercussions in morphology since all preverbs referring to the 1dimensionality of the ground share some phonological substance, namely /IV/, which might be analysed as a marker for 1-dimensionality of the ground referent. This supposed morpheme however is not productive in modern Laz and cannot be used independently. Additionally the morpho-phonological form of this element is similar for only part of the preverbs. While it shows morpho-phonologically triggered change of the vowel for the preverbs cela-, ela-, golaand mola-, the preverb dolo- does not show an alternation in phonological form. Moreover, while the preverbs celaand $e l a$ - alternate between $/ \mathrm{la} /$ and $/ \mathrm{le} /$, the preverbs mola- and gola- alternate between $/ \mathrm{la} / \mathrm{and} / \mathrm{lo} /$. Whether the differences in mopho-phonological behaviour for preverbs containing /lV/ and referring to the 1-dimensionality of a ground referent can be explained diachronically needs further investigation.
} 


$$
\begin{array}{llll}
\text { masa-şi } \quad \text { cindo } & \text { oǩo-ǩŏt-eri } & \text { eo-zun } \\
\text { table-GEN } & \text { surface } & \text { PRV-fold-PTCP } & \text { PRV-lie:3A:SG:PRS } \\
\text { 'It is lying on the top of the table folded.' } &
\end{array}
$$

From the findings so far it seems reasonable to conclude that for descriptions of topological spatial scenes with respect to the surface of a ground, i.e. ON-relations, the meanings of Laz preverbs are based on the parameters [surface contact] and [axial orientation of the surface of the ground]. As (36) shows, however, the use of the preverb goo- is not restricted to descriptions of configurations in which the figure is in contact with a horizontally oriented surface, but is used also in non-contact relations, e.g. a branch expanding above the roof of a house or a cloud above a mountain, cf. (36).

$$
\begin{array}{lll}
\begin{array}{l}
\text { mp̆ula } \\
\text { cloud }
\end{array} & \text { mountain } & \text { goo-xen } \\
& \text { PRV-sit:3A:PRS }
\end{array}
$$

'The cloud is above the mountain.'

(TRPS 36)

For non-contact relations in which the figure is oriented vertically above the ground, however, the preverb $\check{k o \zeta ̌ o-~ h a s ~ t o ~ b e ~ u s e d, ~ c f . ~(37) . ~}$

$$
\begin{aligned}
& \text { lampa masa ǩoža-bun } \\
& \text { lamp table PRV-hang:3A:SG:PRS } \\
& \text { 'The lamp is hanging over the table.' }
\end{aligned}
$$

Thus, we can conclude that for descriptions of non-contact spatial scenes, the axial orientation of the configuration is decisive as well. In order to understand the conceptual system of Laz preverbs we thus have to determine the parameters according to which spatial scenes are conceptualized. As has been illustrated in (36) and (37), for the preverb goo- it is not decisive whether the figure is in contact with an upper surface but rather, whether the figure is oriented horizontally with respect to the ground. Most of the preverbs presented above are used in descriptions of spatial relations in which the figure is in contact with the ground. But this might as well be a consequence of physical affordances related to gravity. Furthermore it has been argued that with respect to descriptions of relations which from a geometrical perspective are relations of inclusion, for Laz preverbs the axial orientation of the path of the figure is more relevant than whether the figure is in a geometrical-functional relation of inclusion. As it appears, for Laz the axial orientation of the path of the figure is a more prominent conceptual parameter than topological-functional ones such as [surface contact/surface support] and [inclusion/containment].

Hence, to summarize the findings for descriptions of topological configurations so far, we find that firstly, the shape property of the ground referent is a relevant parameter according to which the preverbs are chosen for descriptions of static spatial scenes. This parameter can have one of the four values listed in the following table. Exemplary preverbs are listed in the right column: 


\begin{tabular}{|l|l|l|}
\hline i) & ground is 1-dimensional: & gola-, cela- \\
\hline ii) & ground is cylindrical: & dolo- \\
\hline iii) & ground is dense, narrow: & meş̌ka- \\
\hline iv) & ground forms a heap: & eo- \\
\hline
\end{tabular}

Table 4: The Parameter [shape property of the ground-referent]

Secondly, the axial orientation of the path of the figure, i.e. the path which the figure covers before it achieves its location, is relevant for the choice of a preverb. The parameter of axial orientation can have one of three values. Exemplary preverbs are listed in the right column:

\begin{tabular}{|l|l|l|}
\hline i) & vertical orientation: & ce-, dolo-, cela-, eo- \\
\hline ii) & horizontal orientation: & goo-, gola-, mola-, meşǩ $a-$ \\
\hline iii) & neutral: & me-, mo- $^{-}$ \\
\hline
\end{tabular}

Thirdly, the parameter deictic perspective is relevant, cf. also section 4.4 below. It can have one of two values listed in the following table. Exemplary preverbs are listed in the right column:

\begin{tabular}{|l|l|l|}
\hline i) & towards deictic center: & mo-, mola- \\
\hline ii) & away from deictic center: & me- \\
\hline \multicolumn{3}{|c|}{ Table 6: The Parameter [deictic perspective] }
\end{tabular}

\subsection{Source Constructions}

The fact that the axial orientation of the configuration is a decisive parameter for the use of the preverbs in Laz is also supported by data elicited for dynamic spatial configurations in which the figure-referent is moving away from the ground-referent (source constructions). While for stance and goal constructions Laz has the above described complex system of preverbs, for source constructions the number of preverbs is much smaller and the choice of the preverb in these cases is only determined by the parameter of axial orientation and is neither determined by the geometrical-functional concepts inclusion and surface nor by the parameter of shape. ${ }^{8}$ The data presented in (38) - (41) give some illustrative examples.

(38) gama- 'out of, away from (Ground is horizontal (38) or neutral (39))':

porça dolabi mola-b-dum $\rightarrow$ dolabi-sa gamo-

dress wardrobe in-1A-put:SG:PRS

'I put the dress into the wardrobe.'

wardrobe-MOT out-1A-VV-take:SG:PRS

'I take it out of the wardrobe.'

(38b) cari soba meşǩa-b-dum

bread oven in-1A-put:SG:PRS

$\rightarrow$ soba-şa gamo-b-i-yam

'I put the bread into the oven.'

oven-MOT out-1A-VV-take:SG:PRS

'I take it out of the oven.'

\footnotetext{
${ }^{8}$ In contrast to e.g. German or English, where the geometrical-functional concepts [containment/inclusion] and [surface contact] apply to locational and goal as well as to source expressions: Grm. in -> aus, auf/an -> von...runter/weg; Engl. in -> out, on -> from.
} 
çitabi ǩapayi mo-b-dum $\rightarrow$ ǩapayi-şa gamo-b-i-yam book slip.case into-1A-put:SG:PRS slip.case-MOT out-1A-VV-take:SG:PRS 'I put the book into the slip case.' 'I take it out of the slip case.'

(40) $e$ - 'out of, away from (Ground is below)':
oş̌ruri tasi ce-b-dum apple bowl in-1A-put:SG:PRS 'I put the apple into the bowl.'

(40b) $\begin{array}{lll}\text { ǩuzi } & \text { bardayi } & \text { dolo-b-dum } \\ \text { spoon } & \text { glass } & \text { in-1A-put:SG:PRS }\end{array}$ 'I put the spoon into the glass.'

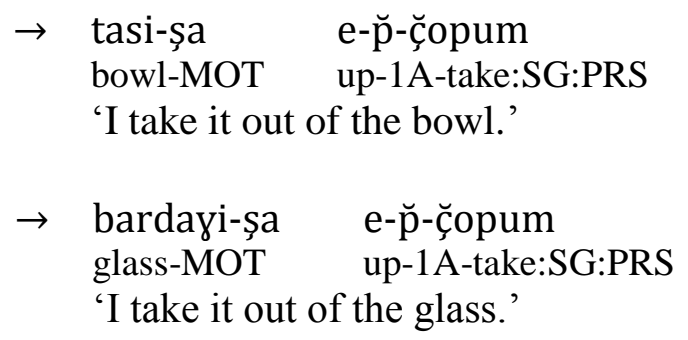

*gamo-b-iyam
(40c)
$\begin{array}{lll}\text { çitabi } & \text { ti } & \text { goo-b-dum } \\ \text { book } & \text { head } & \text { on-1A-put:SG:PRS }\end{array}$
$\rightarrow$ ti-şa

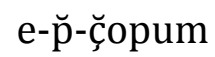
'I put the book on the head.'
head-MOT up-1A-take:SG:PRS
'I take it from the head.'

(41) $c e-$ '(out of), away from (Ground is above)':
$\begin{array}{lll}\text { çanta } & \text { dolabi } & \text { goo-b-dum } \\ \text { bag } & \text { wardrobe } & \text { on-1A-put:PRS }\end{array}$
$\rightarrow$ dolabi-şa
wardrobe-MOT
ce-b-i-yam
down-1A-VV-
take:SG:PRS
'I put the bag on top of the wardrobe.' 'I take it down from the wardrobe.'
cp:
(41b)
$\begin{array}{lll}\text { çanta } & \text { hali/masa } & \text { goo-b-dum } \\ \text { bag } & \text { rug/table } & \text { on-1A-put:PRS }\end{array}$
$\rightarrow$ hali-şa/masa-şa e-
'I put the bag on the rug/table.'
rug/table-MOT up-1A-take:SG:PRS
'I take it from the rug/table.'

In sum, for the description of goal-directed spatial relations we find that the figure's motion path away from the ground is decisive for the choice of the preverb. In cases where the starting location of the figure is above the torso height of the agent, like the top of a wardrobe, the preverb ce- 'down' is chosen, relating to the fact that the figure's path is a downward motion. In cases where the path of the figure-referent follows an upward motion with respect to the torso of the agent, e.g. when lifting something from a pannier or a table, the preverb $e$ - 'up' is used. In all other cases, i.e. where the motion path of the figure is horizontal or not further specified, the preverb gama-'out' is selected.

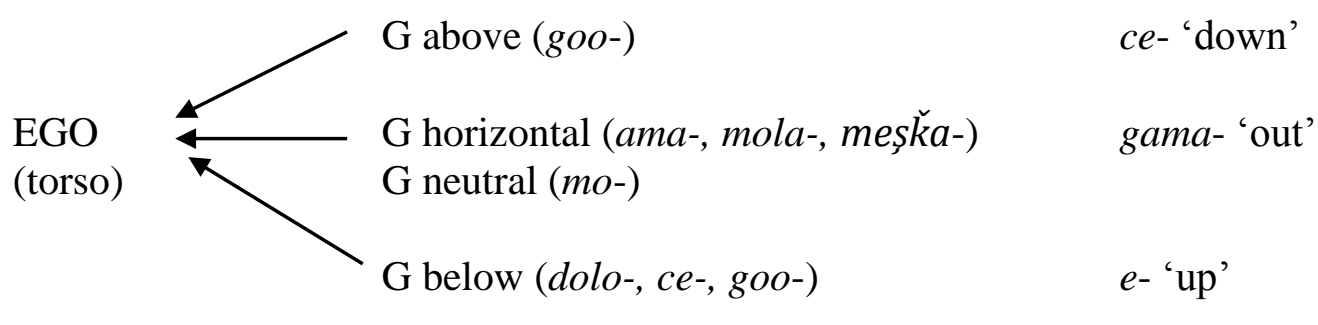

Figure 2: Subsystem of Preverbs Expressing Source Relations 


\subsection{Deixis}

For one preverb used in descriptions of topological configurations, the preverb mo-, we find that the decisive feature is neither based on the axial orientation nor on the shape properties of the ground. In most cases, the use of the preverb mo- in descriptions of topological spatial scenes comprises scenes which from a geometrical perspective are circumvential configurations, i.e. configurations in which the figure is in contact with the surface region of the ground-referent in a circular fashion, e.g. a ring on a finger (42a), a shoe on a foot (42b), a slipcase around a book (42c).

$\begin{array}{lll}\text { maçindri } & \text { kiťi } & \text { mo-zun } \\ \text { ring } & \text { finger } & \text { PRV-lie:3A:SG:PRS }\end{array}$

'The ring is on the finger.'

(TRPS 10)

$\begin{array}{lll}\check{\text { ǩuçxe modvala }} & \check{\text { ǩuçxe }} & \text { mo-zun } \\ \text { shoe } & \text { foot } & \text { PRV-lie:3A:SG:PRS }\end{array}$

'The shoe is on the foot.'

(TRPS 21)

\begin{tabular}{|c|c|}
\hline$(42 c)$ & $\begin{array}{l}\text { kitabi } \\
\text { book }\end{array}$ \\
\hline
\end{tabular}

'The book is in the slip case.'

On scrutiny, the data reveal that it is not the geometrical parameter of circumventionality that is decisive for the use of the preverb mo-, but rather whether the figure is conceptualised as being a functional part of the ground or as canonically belonging to the ground. This can be shown by two observations. The first is that Laz has another preverb which is used in descriptions of circumventional configurations, the preverb go-. This preverb can be used in static, cf. (43a), as well as dynamic spatial configurations in which a figure circumvents a ground-referent, cf. (43b). It can also be used for undirected motion within a region (43c). For all of these situations, the preverb mo- cannot be used.

$$
\begin{array}{lll}
\text { toçi } & \text { çoki } & \text { gV-o-ǩorun } \\
\text { rope } & \text { root } & \text { PRV-VV-be.wound:[3>3]SG:PRS }
\end{array}
$$

'The rope is wound around the root.'

(TRPS 55)

$$
\text { mžu ko-gv-a-̌̌orey }
$$

cherrylaurel.tree MOD-PRV-VV-wind:[3>3]PL:PAST.PFV

'(The swarming bees) surrounded the cherry laurel tree.' (Kutscher \& Genç 1998:51)

$\begin{array}{lll}\text { g-u-ǩă̆aman } & \text { mutu } & \text { var-a-xenenan } \\ \text { PRV-VV-walk:3A:PL:PRS } & \text { something } & \text { NEG-VV-do[POT]:3U:PL:PRS }\end{array}$

'(She choked,) they walk around everywhere, but nobody can do anything.' (Kutscher \& Genç 1998: 41) 
The second finding is that the preverb mo- is used in certain spatial configurations which geometrically are surface contact configurations, e.g. a lid on a pot (44).

$\begin{array}{lll}\text { ǩapayi } & \text { tencere } & \text { mo-zun } \\ \text { lid } & \text { pot } & \text { PRV-lie:3A:SG:PRS }\end{array}$

'The lid is on the pot.' (in case of lid belonging to pot)

If the preverb mo- is replaced with the preverb goo- (normally used for descriptions of support from below/superposition-configurations, cf. (27) above), the reading of the expression changes, cf. (45).

$\begin{array}{lll}\text { ǩapayi } & \text { tencere } & \text { goo-zun } \\ \text { lid } & \text { pot } & \text { PRV-lie:3A:SG:PRS }\end{array}$

'The lid is on the pot.' (in case of lid too big for pot)

Whereas the use of the preverb mo- in (44) expresses that the lid on the pot is the one which fits the pot, the use of the preverb goo- expresses that the lid does not fit the pot. Language consultants give the additional information that they have the feeling that mo-means that the lid "belongs" to the pot. Figure 3 gives an illustrative overview on the range of uses for the preverb $m o$ - when used in descriptions of static spatial configurations.

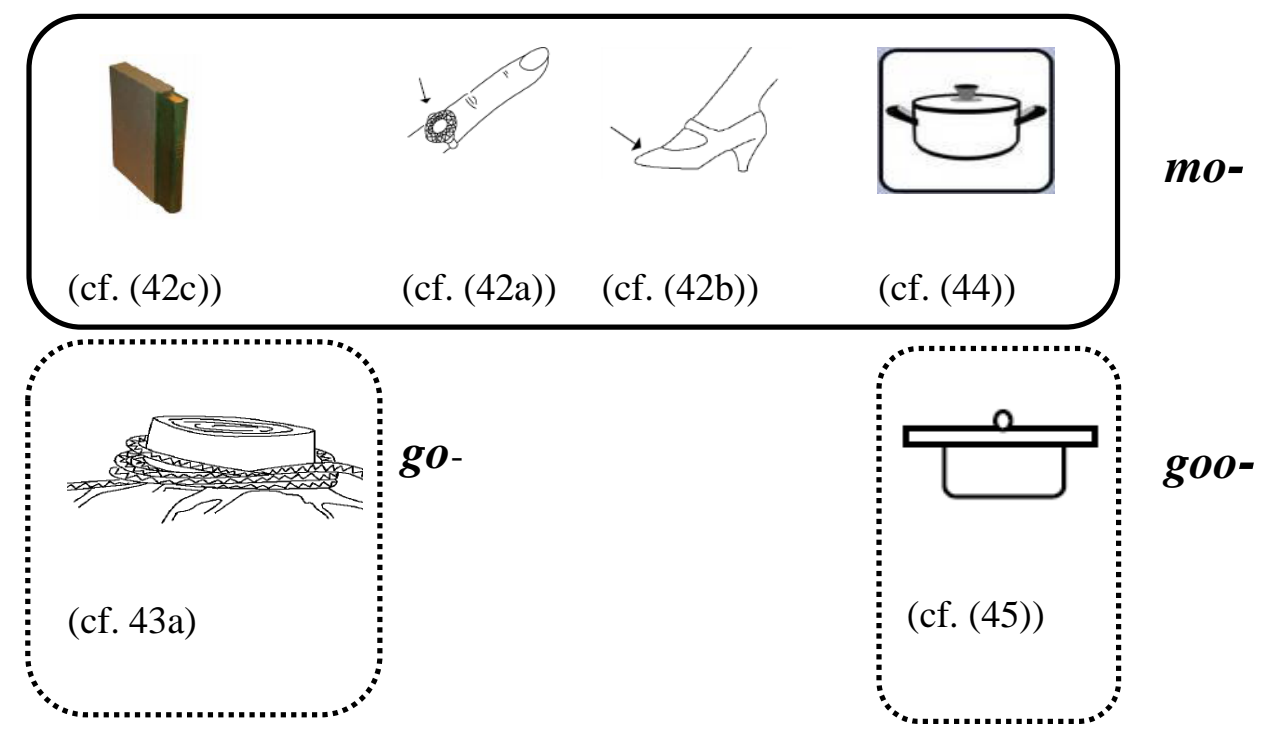

Figure 3: The Use of the Preverb mo- in Descriptions of Static Spatial Scenes

In order to understand the meaning and use of the preverb mo- in descriptions of static topological configurations, one has to take into consideration that with verbs of motion the preverb mo- has a deictic function, i.e. it marks that the figure moves towards the deictic center, cf. (46a). For motion away from the deictic center, the preverb me- is used (46b).

$$
\begin{array}{llll}
\text { var-idu } & \text { ama } & \text { askere-pe } & \text { ko-mo-xtey } \\
\text { NEG-leave:3A:SG:PAST.PFV but } & \text { soldier-PL } & \text { MOD-PRV-go:3A:PL:PAST.PFV } \\
\text { 'He didn't leave but the soldiers came (to his house).' (Kutscher \& Genç 1998: 224) }
\end{array}
$$




me-xti ya k-o-žedi
PRV-go:2A:SG:IMPER QUOT MOD-VV-see:[2>3]SG:IMPER QUOT
"“(There is something on the top of the mountain.) Go there and look at what it is!"”
(Kutscher \& Genç 1998: 24f.)

The deictic use of the preverbs is not restricted to motion verbs but for instance can be found in verbs of manipulation, e.g. the opening and closing of a drawer (47). Here the use of the preverb mo- refers to the fact that the drawer moves in direction of the agent (the prototypical deictic center), cf. (47b), and the preverb me- refers to the fact that the drawer moves away from the agent, cf. (47a).

(47) $m e-/ m o$ - 'out of, away from (deictic)':

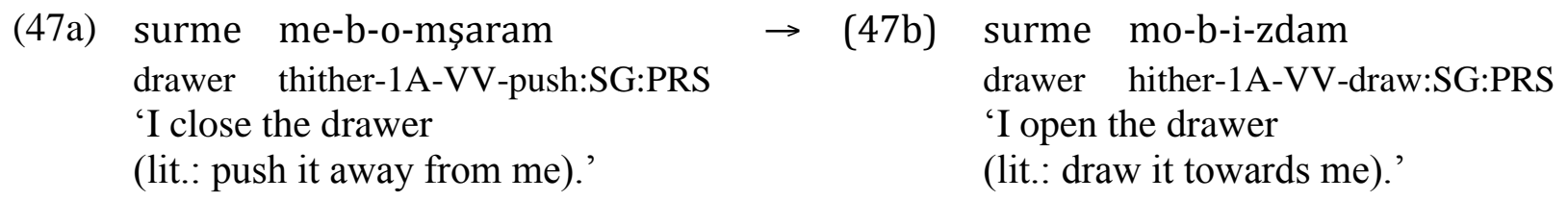

In conclusion, the use of the preverb mo- in the description of static spatial scenes is best explained by recurring to the deictic semantics of this preverb. Like the preverbs in section 4.1 and 4.2, the preverb mo- refers to the path which the figure covers on its way to the final location, but in contrast to the spatial preverbs, it codes the perspective of the motion path rather than its spatial-directional properties. The deictic center in these spatial configurations is the ground-referent (e.g. the finger in (42a) or the pot in (44)). One of the reviewers pointed out a possible correspondence of the preverb $m o$ - to a Tzeltal positional meaning 'tight fit'. Since Laz has a verb $P R V$-nžoy 'tight fit' which can be combined with every spatial preverb which is semantically adequate (cf. Kutscher/Genç 2007), while mo- definitely has a spatial-orientational meaning component, the analysis suggested in this paper will be maintained.

\section{Typological Remarks: Laz Is Not an IN-ON Language}

The linguistic expression and conceptualisation of spatial relations has been a widely discussed topic in linguistic research within the last twenty to thirty years. Considering that the biological basis of the cognitive apparatus is shared by all human beings, it is assumed that the perception of spatial scenes is processed on shared principles of signal processing and signal interpretation. A standard assumption concerning the linguistic expressions of topological spatial scenes is that these are grounded in geometrical-functional concepts (Vandeloise 1986, Nüse 1999, Coventry \& Garrod 2004) and that concepts like INCLUSION/CONTAINMENT, SURFACE/SUPERPOSITION are universal primitives (Miller \& Johnson-Laird 1976, Wunderlich 1986, Klein 1991, Landau \& Jackendoff 1993) which can not only be found as basic semantic features cross-linguistically but also find their expression as basic members of the lexicon. Recent research shows, however, that the morpho-syntax and semantics of spatial expressions is rather diverse across languages, i.e. one cannot find the expected semantic uniformity of topological expressions cross-linguistically (e.g. Levinson 2003, Levinson \& Wilkins (eds.) 2006). It is argued that the conceptualisation of space is not only dependent on biological but also on linguistic and cultural factors. These researchers also argue for universal 
ordering principles underlying linguistic structure (e.g. Bowerman \& Chooi 2001, Levinson \& Meira 2003, Brala 2007). But instead of universal conceptual categories, it is argued, the conceptual domain of topological space is structured by universal ordering principles resulting in an implicational hierarchy comparable to the hierarchy found for basic colour terms. It is assumed that topological spatial expressions cover adjacent sections of a semantic space which is thought of as ordered according to universal conceptual principles (the so-called similarity space). Thus, for the spatial sub-domain of topological relations, Bowerman \& Choi (2001) and Levinson \& Meira (2003) state that cross-linguistically, concepts of topological spatial relations are ordered along the so-called IN-ON-scale. Figure 4 represents this scale as it is supposed by Levinson \& Meira (2003: 488). Although the representations of the supposed scale differ from author to author (cp. e.g. Bowerman \& Choi (2001) with Levinson \& Meira (2003) and Brala (2007)), the overall idea is that configurations are ordered along geometric-functional similarities with full containment and superposition forming the endpoints of the scale. It is supposed that a spatial relator is restricted to denoting only adjacent configurations of the scale, as is illustrated with English prepositions in figure 4. As became evident from the discussion of the Laz data in section 4, the preverbs in Laz, although functionally equivalent to adpositions and local cases on the ground of which the scale was established, do not adhere to the ordering principles stated by the IN-ON-scale.

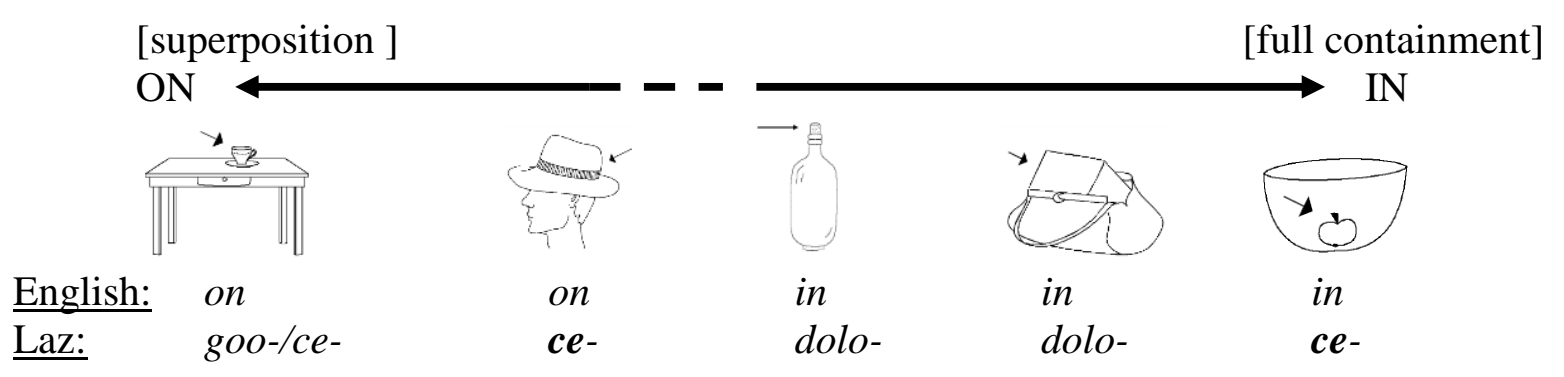

Figure 4: IN-ON-scale (Levinson \& Meira 2003: 488) with English and Laz example data

As figure 4 shows, Laz contradicts the supposed universality of semantic ordering principles underlying the IN-ON-scale. For instance, with respect to the Laz preverb ce- we find that it covers discontinuous parts of the scale. It applies for the configurations 'hat on head' and 'apple in bowl' but not for 'cork in a bottle neck' and 'box in a bag'. As became evident in section 4, geometrical-functional concepts such as [surface/superposition] and [inclusion/containment] are not the primary conceptual parameters underlying the meaning of Laz preverbs. For Laz, the parameters [axial orientation], [shape property of the ground] and [deictic perspective] are relevant for the conceptualization of both static and dynamic spatial scenes.

In sum, the system of spatial preverbs which are used in descriptions of spatial scenes in Laz is structured as presented in figure 5 . 


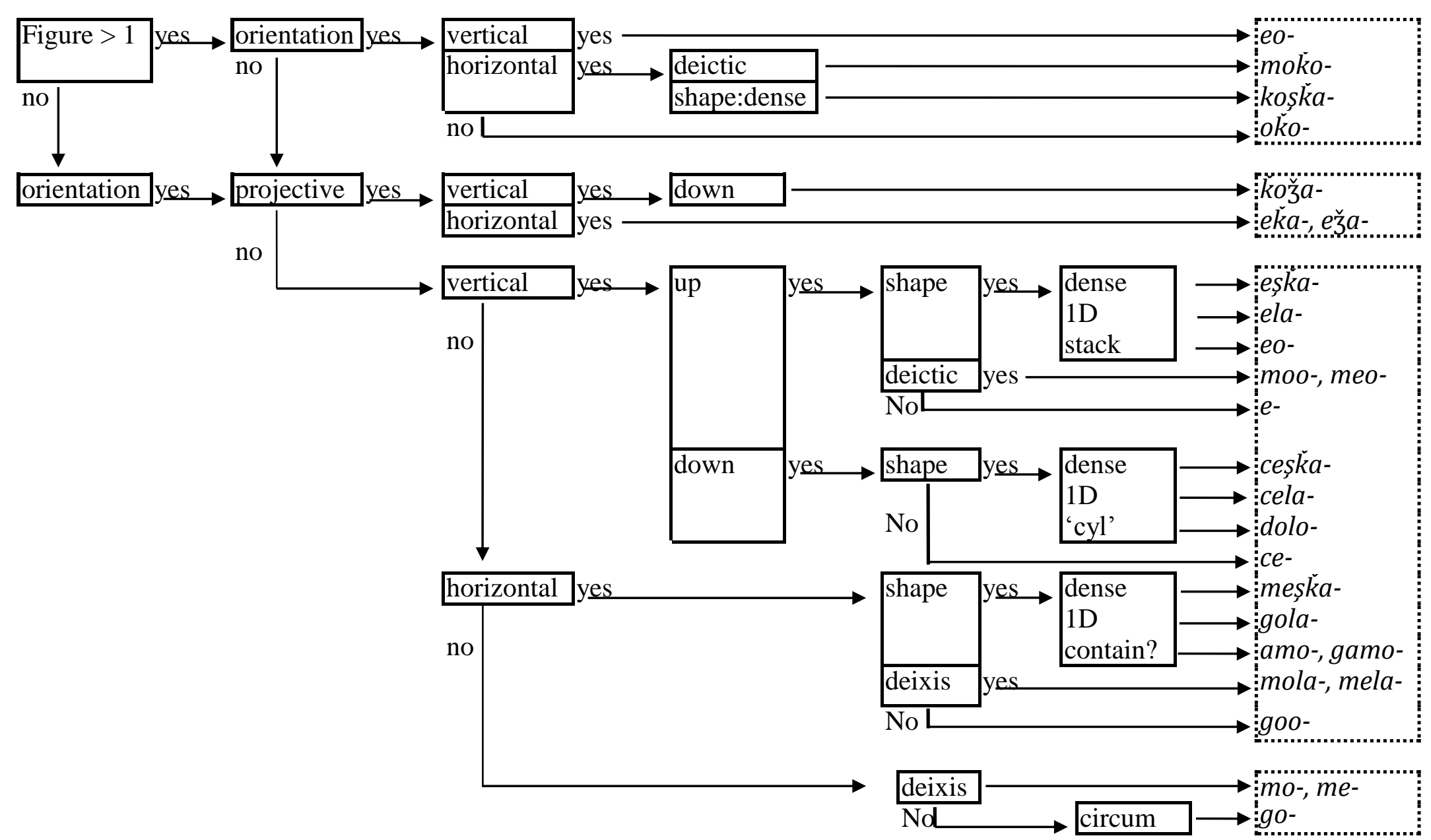

Figure 5: Flowchart of Concepts Relevant for the Use of Spatial Preverbs in Laz 


\section{Summary}

In sum, the data in this paper show that Laz means for the descriptions of spatial relations give some interesting insights in the differences and commonalities of spatial conceptualization.

It has been shown that Laz prefers the satellite-framed strategy, i.e. motion-manner conflation in the roots of motion verbs. With respect to locative expressions it belongs to the multi-verb-type languages. Ardeşen-Laz differs from the other varieties of Laz with respect to its spatial cases; it has a motative case which conflates the allative with the ablative function and thus has a spatial case which seems to be typologically exceptional.

Spatial configurations are expressed mainly in the verbal complex. Preverbs relate to the configurational properties of the ground while the verb root focuses on the properties of the figure. It has been shown that even in description of static spatial scenes the use of Laz spatial preverbs relates to the path along which the figure moves or is moved to achieve its final locative position. Whether the figure is in a containment- or surface-relation then follows from worldknowledge, i.e., is the result of pragmatic inference by the hearer. It has been argued that the parameters i) [axial orientation of the configuration] (with the values [vertical], [horizontal] and [neutral]), ii) [shape property of the ground] (with the values [1D], [cylindrical], [dense], [heap]), and iii) [deictic perspective] (with the values [towards deictic center/belonging-to], [away from deictic center]) are the relevant meaning components of Laz preverbs. It has further been argued that for Laz, geometrical-functional spatial concepts such as [surface/superposition] and [inclusion/containment] are not the primary spatial concepts and that the IN-ON-scale proposed e.g. by Bowerman \& Choi (2001) and Levinson \& Meira (2003) does not hold for spatial relators in Laz.

$\begin{array}{ll}\text { Abbreviations } \\ \text { A } & \text { Actor } \\ \text { CAUS } & \text { causative } \\ \text { cyl } & \text { cylindrical } \\ \text { DAT } & \text { dative } \\ \text { F } & \text { Figure } \\ \text { FUT.PFV } & \text { future perfective } \\ \text { G } & \text { Ground } \\ \text { IMPER } & \text { imperative } \\ \text { MOD } & \text { speaker modality/focus particle } \\ \text { MOT } & \text { motative case } \\ \text { NEG } & \text { negation } \\ \text { NOM } & \text { nominative } \\ \text { P } & \text { person } \\ \text { PAST.PFV } & \text { past perfective } \\ \text { PL } & \text { plural } \\ \text { POSS } & \text { possessive } \\ \text { POT } & \text { potential } \\ \text { PRS } & \text { present tense } \\ \text { PRV } & \text { preverb } \\ \text { PTCP } & \text { participle } \\ \text { QU } & \text { question marker }\end{array}$




$\begin{array}{ll}\text { QUOT } & \text { quotative marker } \\ \text { SG } & \text { singular } \\ \text { TAM } & \text { tense aspect mood } \\ \text { U } & \text { Undergoer } \\ \text { VV } & \text { version vowel } \\ {[>]} & \text { verbform is marked for two arguments, subject }(=A) \text { acting on object }(=U)\end{array}$

\section{References}

Andrews, Avery 1985. The major functions of the noun phrase. In: Shopen, Timothy (ed.) Language typology and syntactic description, vol.1: Clause structure. Cambridge: University, 62-154.

Ameka, Felix K. and Stephen C. Levinson (eds.). 2007. The Typology and Semantics of Locative Predicates: Posturals, Positionals and Other Beasts. Linguistics 45 (5/6).

-----. and Stephen C. Levinson. 2007. Introduction. In: Ameka and Levinson (eds.), 847-872.

Anderson, Ralph D. 1963. A Grammar of Laz. Dissertation, University of Texas. Ann Arbor University Microfilms.

Arkadiev, Peter M. 2008. Thematic roles, event structure, and argument encoding in semantically aligned languages. In: The Typology of Semantic Alignment, ed. by Mark Donohue and Søren Wichmann, 101-120. Oxford: University.

Boeder, Winfried. 1968. Über die Versionen des georgischen Verbs. Folia Linguistica 2 (1/2), 82-152.

Bowerman, Melissa and Soonja Choi. 2001. Shaping meanings for language: universal and language-specific in the acquisition of spatial semantic categories. In: Language acquisition and conceptual development, ed. by Melissa Bowerman and Stephen Levinson, 475-511. Cambridge: University.

Brala, Marija M. 2007. Spatial 'on' - 'in' categories and their prepositional codings across languages: Universal constraints on language specificity. In: Ontolinguistics: How ontological status shapes the linguistic coding of concepts, ed. by Andrea C. Schalley and Dietmar Zaefferer. (Trends in linguistics: Studies and Monographs 176), 299-330. Berlin: Mouton de Gruyter.

Coventry, Kenny R. and Simon C. Garrod. 2004. Saying, Seeing and Acting: The Psychological Semantics of Spatial Prepositions. Hove/New York: The Psychological Press.

Craig, Colette and Kenneth Hale. 1988. Relational preverbs in some languages of the Americas: Typological and historical perspectives. Language 64(2), 312-344.

Creissels, Denis. 2006. Encoding the distinction between location, source, and destination: A typological study. In: Space in Languages: Linguistic Systems and Cognitive Categories, ed. by Maya Hickmann and Stéphane Robert. (Typological Studies in Language 66), 19-28. Amsterdam: Benjamins.

Donohue, Mark and Søren Wichmann (eds.). 2008. The Typology of Semantic Alignment. (Oxford Linguistics). Oxford: University.

Dryer, Matthew S. 1986. Primary Objects, Secondary Objects, and Antidative. Language 62, 808-845.

Herskovits, Annette. 1986. Language and spatial cognition. An interdisciplinary study of the prepositions in English. (Studies in Natural Language Processing). Cambridge: University. 
Holisky, Dee A. 1991. Laz. In: The Indigenous Languages of the Caucasus. Bd.1: The Kartvelian Languages, ed. by Alice C. Harris. (Anatolian and Caucasian Studies), 395-472. Delmar/New York: Caravan Books.

Ihara, Hiroko \& Ikuyo Fujita. 2000. A cognitive approach to errors in case marking in Japanese agrammatism: The priority of the goal $-n i$ over the source -kara. In: Constructions in cognitive linguistics: Selected papers from the fifth international cognitive linguistics conference, Amsterdam, 1997, ed. by Ad Foolen and van der Leek, 123-140. Amsterdam: Benjamins.

Ikegami, Yoshihiko. 1987. 'Source' vs. 'Goal': A Case of Linguistic Dissymmetry. In: Concepts of Case, ed. by René Dirven and Günter Radden. (Studien zur englischen Grammatik 4), 122-145. Tübingen: Narr.

Klein, Wolfgang. 1991. Raumausdrücke. Linguistische Berichte 132, 77-114.

Klimov, G. A. 1974. On the character of active languages. Linguistics 131, 11-23.

Kutscher, Silvia. 2001. Nomen und nominales Syntagma im Lasischen. Eine deskriptive Analyse des Dialekts von Ardeşen. (Studies in Caucasian Languages 17). München: Lincom Europa.

-----. 2003. Raumkonzeption im lasischen Verb: Das System der deiktischen und topologischen Präverbien. In: Kaukasische Sprachprobleme. Beiträge zu den Kaukasistentagungen in Oldenburg 1995 - 2001, ed. by Winfried Boeder. (Caucasica Oldenburgensia 1), 223-246. Oldenburg: BIS.

----. 2008. The language of the Laz in Turkey: Contact-induced change or gradual language loss? Turkish Languages 12, 82-102.

-----. 2009. Kausalität und Argumentrealisierung. Zur Konstruktionsvarianz bei Psychverben in europäischen Sprachen. (Linguistische Arbeiten 528). Tübingen: Niemeyer.

----. 2010. When 'towards' means 'away from': The case of directional-ablative syncretism in the Ardeşen variety of Laz (South-Caucasian). Sprachtypologie und Universalienforschung 63 (3), 252-271.

Kutscher, Silvia and N. Sevim Genç. 1998. Ardeşen narrates - Ardeşeni na isinapinenpe. A collection of Laz spoken texts with glosses and translations into English, German and Turkish. (Languages of the World/Text collections 14). Unterschleißheim/München: Lincom Europa.

----. 2007. Laz positional verbs: semantics and use with inanimate Figures. In: Felix Ameka and Stephen Levinson (eds.), 1029-1064.

Lacroix, René. 2009. Description du dialecte laze d'Arhavi (caucasique du sud, Turquie). Grammaire et textes. Thèse de doctorat en Sciences du Langage. Université Lumière Lyon 2.

Lakusta, Laura and Landau, Barbara. 2005. Starting at the end: The importance of goals in spatial language. Cognition 96, 1-33.

Landau, Barbara and Ray Jackendoff. 1993. 'What' and 'where' in spatial language and cognition. Behavioral and Brain Science 16, 217-265.

Lazoğlu, Fahri and Wolfgang Feurstein. 1984. Lazuri Alfabe. Lazca Alfabe. Entwurf eines lazischen Alphabetes. Parpali 1. Lazuri Carelepe. Laz dili ve kültürü yayınları. Schriftenreihe zur lazischen Kultur. Freiburg i.Br.: Privately printed.

Lehmann, Christian. 1983. Latin Preverbs and Cases. In: Latin Linguistics and Linguistic Theory. Proceedings of the $1^{\text {st }}$ international colloquium on Latin linguistics, Amsterdam, April 1981, ed. by Harm Pinkster, 145-161. Amsterdam: Benjamins. 
Levinson, Stephen C. 2000. H.P. Grice on location on Rossel Island. In: Proceedings of the $25^{\text {th }}$ annual meeting of the Berkeley Linguistic Society. February 12-15, 1999, ed. by Steve S. Chang, Lily Liaw and Josef Ruppenhofer, 210-224. Berkeley: BLS.

-----. 2003. Space in language and cognition. Explorations in cognitive diversity. (Language, culture \& cognition 5). Cambridge: University.

Levinson, Stephen and Sérgio Meira. 2003. 'Natural Concepts' in the spatial topological domain - Adpositional meanings in crosslinguistic perspective: An exercise in semantic typology. Language 79(3), 485-516.

Levinson, Stephen and David Wilkins. 2006. The background to the study of the language of space. In: Grammars of space, ed. by Stephen Levinson and David Wilkins, 1-23. Berlin: de Gruyter.

Mattissen, Johanna 1995. Verbmorphologie. In: Das Mut'afi-Lazische, ed. by Silvia Kutscher, Johanna Mattissen and Anke Wodarg. (Arbeitspapier 24 (N.F.)), 21-36. Köln: Institut für Sprachwissenschaft.

-----. 2001. Tense and Aspect in Laz. In: Aktionsart and Aspectotemporality in Non-European Languages, ed. by. Karin Ebert and Fernando Zúñiga. (Arbeiten des Seminars für Allgemeine Sprachwissenschaft), 15-48. Zürich: Seminar für Allgemeine Sprachwissenschaft.

Miller, George and Philip N. Johnson-Laird. 1976. Language and perception. Cambridge, MA: Harvard University Press.

Nüse, Ralf. 1999. General meanings for German an, auf, in, and unter. Towards a neoclassical semantics of topological prepositions. Dissertation, Humboldt-University Berlin.

Regier, Terry. 1996. The human semantic potential: Spatial language and constrained connectionism. Cambridge: MIT Press.

Regier, Terry and Mingyu Zheng. 2007. Attention to Endpoints: A Cross-Linguistic Constraint on Spatial Meaning. Cognitive Science 31, 705-719.

Rosen, Georg. 1844. Über die Sprache der Lazen. Lemgo/Detmold: Meyersche Hofbuchhandlung.

Stolz, Thomas. 1992. Lokalkasussysteme. Aspekte einer strukturellen Dynamik. (Pro Lingua 13). Wilhelmsfeld: Egert.

Talmy, Leonard. 1985. Lexicalisation patterns: semantic structure in lexical forms. In: Language typology and syntactic description, vol. 3: Grammatical categories and the lexicon, ed. by Timothy Shopen, 57-201.

----- 2007. Lexical typologies. In: Language typology and syntactic description, volume 3 : Grammatical categories and the lexicon, Second edn., ed. by Timothy Shopen. Cambridge: Cambridge University Press.

Vandeloise, Claude. 1986. L'espace en français: Sémantique des prépositions spatiales. Paris: Editions du Seuil (Travaux Linguistiques). Translated into English (1991) as Spatial Prepositions: A case study from French. Chicago: University.

Wunderlich, Dieter. 1986. Raumkonzepte - Zur Semantik der lokalen Präpositionen. In: NachChomskysche Linguistik, ed. by Thomas Ballmer and Roland Posner. Berlin: de Gruyter, 340-351.

Author's Contact Information:

Silvia Kutscher

Excellence Cluster TOPOI, Humboldt University Berlin \&

Department of General Linguistics, Muenster University

silvia.kutscher@culture.hu-berlin.de 